\title{
Estradiol differentially modulates the exocytotic proteins SNAP-25 and munc-18 in pituitary gonadotrophs
}

\author{
Jürgen M Weiss, Heike Hüller, Stephan Polack, Michael Friedrich, Klaus Diedrich, \\ Oliver Treeck ${ }^{1}$, Georg Pfeiler ${ }^{1}$ and Olaf Ortmann ${ }^{1}$
}

Department of Obstetrics and Gynaecology, University of Luebeck, Luebeck, Germany

${ }^{1}$ Department of Obstetrics and Gynaecology, University of Regensburg, Regensburg, Germany

(Requests for offprints should be addressed to J M Weiss who is now at Department of Obstetrics and Gynaecology, University of Ulm, Prittwitzstr 43, 89075, Ulm, Germany; Email: jmweiss1@ hotmail.com)

\begin{abstract}
Long-term treatment with estradiol increases LH secretion from female gonadotrophs. The mechanisms are not fully clarified yet. Our previous data indicated that sexual steroids might affect late steps in GnRH signal transduction such as exocytosis. The secretion of hormones from neuroendocrine cells requires the merger of secretory vesicles with the plasma membrane. This regulated exocytosis is mediated by specific proteins, which are present in the pituitary gland. Here, we examined whether two of these crucial exocytotic proteins, SNAP-25 and munc-18, are affected by estradiol in female gonadotrophs. Female rat anterior pituitary cells and $\alpha \mathrm{T} 3-1$ cells, derived from a murine immortalized gonadotroph cell line, were treated with $100 \mathrm{pM}$ estradiol for $48 \mathrm{~h}$. LH secretion of anterior pituitary cells, additionally stimulated with eight consecutive pulses of $1 \mathrm{nM} \mathrm{GnRH}$ for $15 \mathrm{~min}$ at an interval of $1 \mathrm{~h}$, was determined by RIA. Gene expression was measured by quantitative RT-PCR and protein expression by immunoblotting. Additionally, quantitative RT-PCR was performed in single rat gonadotrophs to ascribe effects exclusively to intact gonadotrophs. Pulsatile $\mathrm{GnRH}$ enhanced the mRNA expression of SNAP-25 and munc-18 in accordance with the LH secretory response with the greatest increase at the third pulse of $\mathrm{GnRH}$. Estradiol treatment further increased $\mathrm{GnRH}$-induced LH secretion at all $\mathrm{GnRH}$ pulses. SNAP-25 gene expression was significantly decreased at the fifth $\mathrm{GnRH}$ pulse and unaffected at basal after $48 \mathrm{~h}$ of estradiol treatment. In contrast, munc-18 mRNA levels were not significantly affected by estradiol at different $\mathrm{GnRH}$-pulses in mixed anterior pituitary cells, whereas munc-18 gene expression was significantly increased at basal. In $\alpha$ T3-1 cells and single gonadotrophs, long-term estradiol treatment significantly reduced SNAP-25 protein and gene expression. In contrast, the protein and gene expression of munc-18 was significantly enhanced in both $\alpha$ T3-1 cells and single gonadotrophs. In conclusion, munc-18 and SNAP-25 were oppositionally influenced by estradiol. The results suggest that estradiol modulates the expression of exocytotic proteins in gonadotrophs and thus affects LH secretion.
\end{abstract}

Journal of Molecular Endocrinology (2007) 38, 305-314

\section{Introduction}

Previous studies demonstrated that long-term estradiol treatment of rat pituitary gonadotrophs increased basal and agonist-induced LH secretion. The mechanisms are not fully elucidated yet. Modulations of GnRH signal transduction such as calcium signaling and inositol phosphates are in part responsible for the effects of estradiol (Ortmann et al. 1992, 1995). It might well be that steroids affects late steps in GnRH signal transduction like exocytosis (Ortmann et al. 1998).

Exocytosis, the fusion of secretory vesicles with the plasma membrane, is the final step of signal transduction in neuroendocrine cells such as gonadotrophs to release hormones. Before the secretory vesicles, processed at the trans-Golgi region of the cells, fuse with the plasma membrane, they undergo several modifications such as translocation (transport close to the plasma membrane), docking (attachment to the plasma membrane), and priming (maturation that makes them ready for the final $\mathrm{Ca}^{2+}$-triggered step; Stojilkovic 2005). Functional studies have provided intriguing details into how SNARE (soluble N-ethylmaleimide-sensitive factor attachment protein receptors) proteins interact with each other to generate the fusion of lipid bilayers. Regulated exocytosis is controlled and mediated by SNARE proteins. They play a crucial role in the intracellular membrane fusion (Rettig \& Neher 2002). SNARE proteins are either residing in the vesicle membrane (v-SNAREs like synaptobrevin $=$ vesicleassociated membrane protein (VAMP) and synaptotagmin; Borisovska et al. 2005) or in the plasma membrane (syntaxin and synaptosomal-associated protein of $25 \mathrm{kDa}$ (SNAP-25); Sorensen et al. 2002). SNAREs bind to each other by forming a very stable fourstranded coiled-coil core complex, constituted by one coil each from syntaxin and VAMP, and two coils from SNAP-25 (Chen \& Scheller 2001).

DOI: $10.1677 / j m e .1 .02114$ Online version via http://www.endocrinology-journals.org 
Recently, many proteins have been identified that participate in the exocytosis of the pituitary gland (Thomas et al. 1998). Their exact function, however, remains unclear. SNAP-25, originally identified at neuronal synapses, was found in pituitaries (Aguado 1996, Jacobsson \& Meister 1996, Kolk et al. 2004). Since the antisense oligonucleotide of SNAP-25 inhibited TRH-induced prolactin release, SNAP-25 is essential for the release of prolactin in pituitary cell lines (Masumoto et al. 1997). Immunoreactivity of SNAP-25 is enhanced in human prolactinomas as well (Majo et al. 1997). $\mathrm{Ca}^{2+}$. induced LH secretion was significantly decreased after treatment with SNAP-25 antibodies. Furthermore, incubation with GnRH decreased SNAP-25 expression in western blots (Quintanar et al. 2004). Taken together, these results show that SNAP-25 is essential for the secretion of pituitary cells.

Munc-18 seems to be involved in all eukaryotic vesicle trafficking and fusion (Jahn 2000). It lacks membrane targeting domains and is located in the cytoplasm. Munc-18 binds tightly to syntaxin which blocks its interaction with SNAP-25. The dissociation of munc-18 allows the formation of a complex between syntaxin and SNAP-25. VAMP binds to syntaxin (Sudhof 1995). Plasma membrane and vesicle membrane are now capable of fusing and hormones are released. Munc-18 null mutant mice have no synaptic activity in neurons (Verhage et al. 2000). In the absence of munc-18, $\mathrm{Ca}^{2+}$. triggered exocytosis of neuroendocrine cells is minimized, whereas the overexpression of munc-18 increased exocytosis (Voets et al. 2001). These facts demonstrate the importance of munc-18 in exocytosis. Although many details on munc-18 function in different cell types are known, the function of munc18 in gonadotrophs and its interaction with estradiol remain unclear.

To shed light on the actions of estradiol, we examined for the first time the effects of estradiol on the exocytotic proteins SNAP-25 and munc-18 in female gonadotrophs. We concentrated on these proteins, because both are critical components for the exocytosis in pituitaries.

\section{Materials and methods}

\section{Pituitary cell preparation and culture conditions}

Pituitary cells were obtained from ovarectomized adult (200-250 g) female Sprague Dawley rats (Charles River, Kirchborchen, Germany). Single-cell suspensions were prepared by controlled trypsinization as described previously (Ortmann et al. 1990). Briefly, pituitary glands were collected after decapitation and neural lobe was separated. Anterior pituitaries were cut into small pieces. After digestion with $0.5 \%$ trypsin, they were treated with DNase and $0 \cdot 1 \%$ trypsin inhibitor. After gentle pipetting, dispersed cells were separated by centrifugation. Cell viability was determined using the Trypan Blue exclusion method (usually $>95 \%$ ). Cells were incubated in medium 199 (Biochrom KG, Berlin, Germany) with Hank's salts and L-glutamine, supplemented with $1.4 \mathrm{~g} / 1$ sodium bicarbonate, $10 \mu \mathrm{g} / \mathrm{ml}$ streptomycin, $100 \mathrm{U} / \mathrm{ml}$ penicillin, and $10 \%$ horse serum, pretreated with $2 \%$ charcoal (Norit A) and $0 \cdot 2 \%$ Dextran T 70 (Pharmacia, Uppsala, Sweden) to eliminate steroids. To allow cell attachment, cultures were incubated for $48 \mathrm{~h}$ in humidified incubators at $37^{\circ} \mathrm{C}$ in an atmosphere of $5 \% \mathrm{CO}_{2}$ and $95 \%$ air.

\section{Estradiol and GnRH treatment}

After $48 \mathrm{~h}$, cells were treated for another $48 \mathrm{~h}$ period with $100 \mathrm{pM}$ estradiol in serum-free media. Estradiol was dissolved in ethanol and the final concentration of ethanol in the culture media was $0 \cdot 2 \%$. Controls received media containing $0.2 \%$ ethanol alone (vehicle). After $48 \mathrm{~h}$ treatment with estradiol, mixed anterior pituitary cells were washed and stimulated with eight consecutive GnRH pulses of $1 \mathrm{nM}$ GnRH for $15 \mathrm{~min}$ at an interval of $1 \mathrm{~h}$ in a static culture system. GnRH pulses were administered by a pipette. After each GnRH pulse, media were removed and replaced by fresh media and kept for $45 \mathrm{~min}$. Media for LH measurements were taken before and after each pulse. Only gonadotrophs react to their physiological agonistic stimulus GnRH. Therefore, we assume that the described effects could be ascribed to gonadotrophs.

\section{LH measurement}

Media were collected and analyzed for their hormone content by RIA, using the reference preparation RP-3 from the National Pituitary Agency and Dr Parlow (Harbor-University of California-Los Angeles Medical Center, Torrance, CA, USA). The intra- and inter-assay variations were below $8 \%$.

\section{aT3-1 cell culture}

Since mixed populations of pituitary cells contain only between 5 and $10 \%$ of gonadotrophs we employed $\alpha \mathrm{T} 3-$ 1 cells, an immortalized gonadotroph-derived cell line was kindly provided by Dr P L Mellon (San Diego, CA, USA), to save rats and to attribute effects to gonadotrophs. Cells were cultured on six-well dishes (500 000 cells/well) in Dulbecco's modified Eagle's medium (DMEM) supplemented with $10 \%$ fetal calf serum (Life Technologies, Karlsruhe, Germany) and $100 \mathrm{mg} / 1$ gentamycin (Biochrom KG). To allow cell attachment, cells were kept for $36 \mathrm{~h}$ in humidified 
incubators at $37^{\circ} \mathrm{C}$ in an atmosphere of $5 \% \mathrm{CO}_{2}$ and $95 \%$ air. At $70-80 \%$ confluency, cells were harvested after detachment with accutase (GiBCO, Wiesbaden, Germany) and treated with $100 \mathrm{pM}$ estradiol in serumfree medium for $48 \mathrm{~h}$.

\section{Immunoblotting}

aT3-1 cells were lysed in RIPA buffer (containing $1 \mathrm{mM}$ PMSF) for $1 \mathrm{~h}$ at $4{ }^{\circ} \mathrm{C}$. Nuclei were removed by centrifugation. Protein concentration was determined according to the method of Bradford (Bio-Rad). Proteins were separated by SDS-polyacrylamide gels (SDS-PAGE), transferred on PVDF membranes and analyzed by immunoblotting as follows: the membranes were blocked in a solution of $5 \%$ milkpowder and $3 \%$ BSA for $1 \mathrm{~h}$. Primary antibody was diluted in blocking buffer (SNAP-25, 1:3000; munc-18, 1:500) and incubated with the membrane overnight. After washing, peroxidase-conjugated secondary antibody (IgG 1:2000) was added for $1 \mathrm{~h}$. Detection of peroxidase activity was performed with enhanced chemiluminescence hyperfilm and kits (Amersham, Freiburg, Germany).

\section{Antibodies used}

SNAP-25a (1:3000), BabCO, Berkley, CA, USA; munc18-2 (1:500), Becton Dickinson, Heidelberg, Germany; $\beta$-actin (1:7500), Sigma; IgG (1:2000), Amersham, Braunschweig, Germany.

\section{Quantitative RT-PCR}

RNA was isolated from rat pituitary cells and $\alpha$ T3-1 cells using TRI reagent (Sigma) according to the manufacturer's instructions. Total RNA $(0 \cdot 5-2 \mu \mathrm{g})$ was reverse transcribed using SuperScript II reverse transcriptase (Invitrogen Life Technologies, Inc.) and $10 \mathrm{pM}$ poly(deoxythymidine) primer in a $10 \mu \mathrm{l}$ total volume reaction. The first $\mathrm{cDNA}$ synthesis reaction was heated to $55^{\circ} \mathrm{C}$ for $5 \mathrm{~min}$ to inactivate the reverse transcriptase and then diluted with $10 \mathrm{mM}$ Tris- $\mathrm{HCl}(\mathrm{pH} \mathrm{7.5)}$ to a final volume of $100-300 \mu \mathrm{l}$. An aliquot $(4 \mu \mathrm{l})$ of cDNA was used for quantification of gene expression. We used DNase digestion after RNeasy silica membrane-based RNA purification to remove any trace of DNA. Specific primers for LH, SNAP-25, and munc-18 were used (Tables 1 and 2). All primers were designed over introns based on the exon/intron gene structures. $\mathrm{MgCl}_{2}$ concentrations were optimized. A typical reaction involved an initial denaturation at $95^{\circ} \mathrm{C}$ for $2 \mathrm{~min}$, followed by 40 cycles of $50^{\circ} \mathrm{C}$ for $1 \mathrm{~min}$, and elongation at $60{ }^{\circ} \mathrm{C}$ for $30 \mathrm{~s}$. A standard melting curve cycle was used to check the quality of amplification and to
Table 1 Primers for quantitative RT-PCR in rat pituitary cells

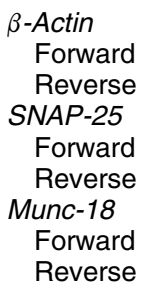

confirm the absence of primer dimer formation. To ensure accuracy, each reaction was repeated 2-5 times per sample. The mean value of the repeat was used for each gene per sample to calculate the ratio between the mean value of the target gene and the internal control gene. The relative level of each gene was expressed by the ratio of the number of transcripts of the gene to an internal control gene which was $\beta$-actin. The data were analyzed using the comparative threshold cycle method, because the efficiency of the target amplification was approximately equal to that of the $\beta$-actin amplification.

\section{Single-cell quantitative RT-PCR}

We have established a quantitative reverse transcriptasePCR (RT-PCR) approach for the analysis of RNA transcript levels in single rat pituitary cells. This approach allowed us to trace back the effects exclusively to intact rat gonadotrophs. Primary pituitary cell cultures were dispersed in $60 \mathrm{~mm}$ tissue culture plates at a density of $1 \times 10^{4}$ cells and incubated as described before. Cells were detached with accutase (PAALaboratories GmbH Catalogue no. L11-007, Vienna, Austria). The pellet was washed twice in cold $\left(4^{\circ} \mathrm{C}\right)$ Dulbecco's PBS (without $\mathrm{Mg}^{2+}$ and $\mathrm{Ca}^{2+}$ ) and diluted in $1 \mathrm{ml} \mathrm{10 \%} \mathrm{polyvinylpyrrolidone} \mathrm{(PVP;} \mathrm{Sigma} \mathrm{P-5288)}$ to ease cell collection in viscous medium.

A drop of the cell mixture was observed under an inverted microscope. Single cells were isolated with a micromanipulator fitted with a pulled microcapillary. A single cell was expelled into a PCR tube filled with

Table 2 Primers for quantitative RT-PCR in $\alpha$ T3-1 cells

\begin{tabular}{|c|c|}
\hline \multicolumn{2}{|l|}{$\beta$-Actin } \\
\hline Forward & 5' GCTCGTCGTCGACAACGGCTC $3^{\prime}$ \\
\hline Reverse & $5^{\prime}$ CAAACATGATCTGGGTCATCTTCTC $3^{\prime}$ \\
\hline \multicolumn{2}{|c|}{ Mouse SNAP-25 } \\
\hline Forward & $5^{\prime}$ ССТССАСТСТTGСTACСTGC $3^{\prime}$ \\
\hline Reverse & $5^{\prime}$ СTCСTCTGCATCTCCTCCAG $3^{\prime}$ \\
\hline \multicolumn{2}{|c|}{ Mouse munc-18-2 } \\
\hline Forward & $5^{\prime}$ ACTCCGCTGACTCTTTCCAA $3^{\prime}$ \\
\hline Reverse & $5^{\prime}$ TCTGGTACTGGGGCATTTTC $3^{\prime}$ \\
\hline
\end{tabular}


$10 \mu$ ice-cold $1 \times$ PCR buffer and frozen immediately in $-80^{\circ} \mathrm{C}$ overnight. First-strand cDNA synthesis was performed using standard protocol with SuperScript II Reverse Transcriptase (Invitrogen). The PCR program consisted of the following cycles: one cycle $(2 \mathrm{~min}$ at $50{ }^{\circ} \mathrm{C}$ and $2 \mathrm{~min}$ at $\left.95^{\circ} \mathrm{C}\right)$ followed by 50 cycles $\left(95^{\circ} \mathrm{C}\right.$ for $15 \mathrm{~s}, 59^{\circ} \mathrm{C}$ for $15 \mathrm{~s}$, and $72^{\circ} \mathrm{C}$ for $20 \mathrm{~s}$.).

All primer pairs span at least one intron so that the PCR product could be distinguished by size from contaminating genomic DNA. All primer pairs were designed to anneal at $59^{\circ} \mathrm{C}$ optimally. Primers are listed in Table 3. Real-time PCR was performed on a DNA Engine Opticon 2 System (MJ Research, Waltham, USA) in a volume of $25 \mu \mathrm{l}$ including $12.5 \mu \mathrm{l} 2 \times$ Platinum SYBR Green qPCR SuperMix (Invitrogen), $0.4 \mu \mathrm{M}$ primer (final concentration) and $2 \mu \mathrm{l}$ template cDNA. All components without cDNA, but DEPC water instead served as negative control. To ensure 'hot start conditions', the Platinum Taq DNA polymerase was complexed with a proprietary antibody that blocks polymerase activity at ambient temperatures. Activity is restored after a denaturation step in PCR cycling, providing an automatic hot start in PCR for increased sensitivity, specificity, and yield. PCRs were optimized for magnesium concentration, primer concentration, and annealing temperature. PCR products were verified with both melting curve analysis and DNA gel electrophoresis. Gonadotrophs were identified by simultaneous detection of LH- $\beta$, which is unique for gonadotrophs.

\section{Quantification with gene-specific standard curves}

Unknown amounts of molecules were determined from gene-specific standard curves using the Opticon Monitor Analysis Software (MJ Research). The cDNA standards were prepared from purified PCR products

Table 3 Primers for single-cell quantitative RT-PCR in rat gonadotrophs

\begin{tabular}{ll}
\cline { 2 - 2 } Rat $\beta$-actin & \\
Product size & $92 \mathrm{bp}$ \\
Forward & $5^{\prime}$-GCTCTCTTCCAGCCTT -3' \\
Reverse & $5^{\prime}$-CGGATGTCAACGTCACACTT-3' \\
Rat $L H$ - $\beta$ & \\
Product size & $99 \mathrm{bp}$ \\
Forward & $5^{\prime}$-ATCACCTTCACCACCAGCAT -3' \\
Reverse & $5^{\prime}$ - GTAGGTGCACACTGGCTGAG -3' \\
Rat SNAP-25 & \\
Product size & 102 bp \\
Forward & $5^{\prime}$-AGCAGAGCTCACGTTGCATT-3' \\
Reverse & $5^{\prime}$-CCTGCAGGTAGCAAGAGTGG-3' \\
Rat Munc-18-2 & \\
Product size & 137 bp $^{\prime}$ \\
Forward & $5^{\prime}$-TATGAGGCCCAGGTGTTCTC-3' \\
Reverse & $5^{\prime}$-TCCTGAAGAGTGGCACACAG-3'
\end{tabular}

(NucleoSpin Extract II, Machery-Nagel, Düren, Germany). The purified PCR products were analyzed and quantified photometrically at $260 \mathrm{~nm}$. Quantified DNA was diluted from $10^{7}$ to $10^{2}$ molecules (standard curve).

\section{Statistical analysis}

Data obtained from 3-4 experiments run in triplicate were pooled, and all the results are expressed as percentage $(\%)$ of control (vehicle-treated), set to $100 \%$. $P$ values $<0.05$ were considered as statistically significant. Statistical differences between each experimental and the control group were analyzed using two-way ANOVA repeated measures and Bonferroni post-test, one-way ANOVA with Dunnett's post-test or unpaired $t$-test respectively.

\section{Results}

\section{Effects of GnRH pulses and estradiol on LH secretion and SNAP-25 and munc-18 gene expression in mixed anterior pituitary cells}

LH secretion was highest and significantly higher than control (from 4 up to $18 \mathrm{ng} / \mathrm{ml}, P<0 \cdot 01$ ) at the fourth GnRH pulse. Estradiol further increased the LH response of mixed anterior pituitary cells to $\mathrm{GnRH}$ pulses with the highest LH secretion of $22 \mathrm{ng} / \mathrm{ml}$ $(P<0 \cdot 01)$ at the third GnRH pulse (Fig. 1A).

Pulsatile GnRH significantly increased the mRNA expression of SNAP-25 and munc-18 in untreated cells in accordance with the LH secretory response compared with basal $(P<0.01$ for SNAP-25 and munc18 mRNA). The greatest increase at the third pulse of GnRH is significantly higher than that at all other GnRH pulses $(P<0 \cdot 001$ for both proteins; Fig. 1B).

After $48 \mathrm{~h}$ of estradiol treatment, the gene expression of $S N A P-25$ was diminished, whereas munc-18 mRNA levels were significantly enhanced $(P=0 \cdot 012$; basal in Fig. 2B).

SNAP-25 levels were significantly decreased by estradiol at the fifth GnRH pulse $(P=0.028)$. In contrast, munc-18 mRNA was increased in estradioltreated cells at the first and third pulse, but this increase did not reach statistical significance (Fig. 2B).

\section{Presence of SNAP-25 and munc-18 in $\alpha$ T3-1 cells}

Since it was not known whether SNAP-25 and munc-18 are present in $\alpha \mathrm{T} 3-1$ cells, we performed immunoblots to identify these proteins in our cell line. We could demonstrate the presence of SNAP-25 and munc-18 in our $\alpha$ T3-1 cells (Fig. 3). 

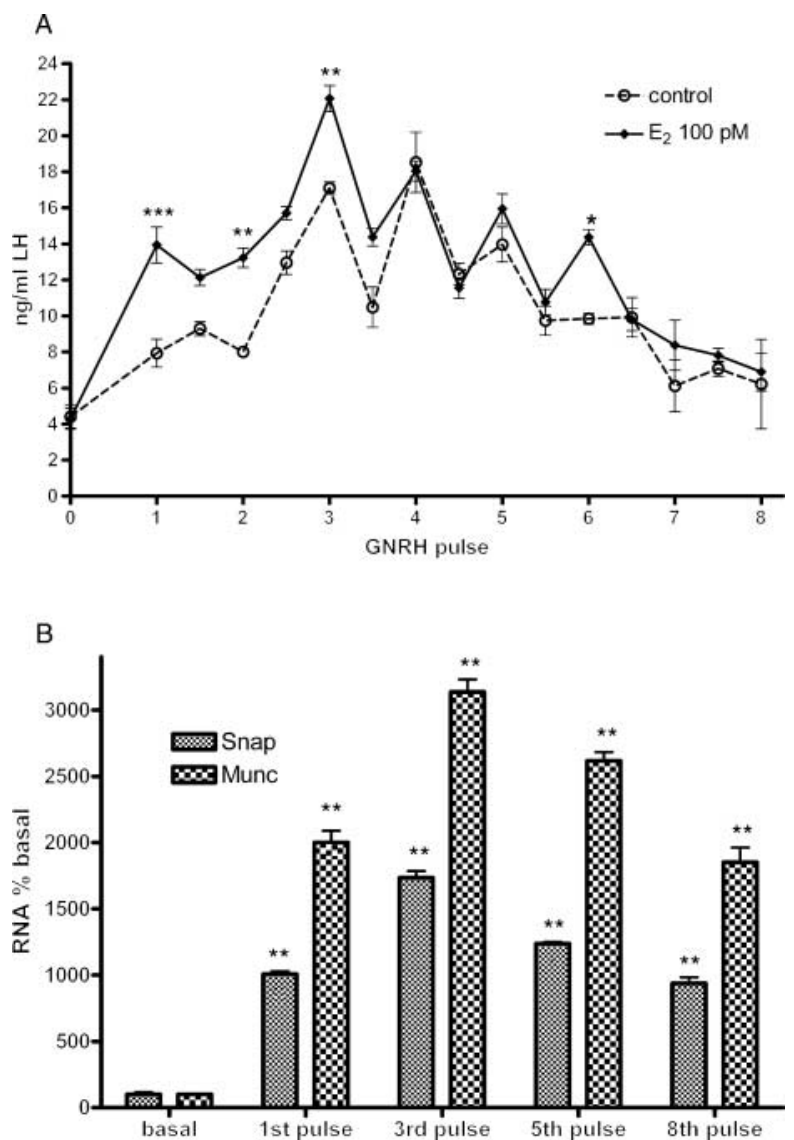

Figure 1 Effects of $\mathrm{GnRH}$ pulses and estradiol on $\mathrm{LH}$ secretion and the gene expression of SNAP-25 and munc-18. (A) Mixed anterior pituitary cells were treated for $48 \mathrm{~h}$ with $100 \mathrm{pM}$ estradiol. Cells were stimulated with eight pulses of $1 \mathrm{nM} \mathrm{GnRH}$ for $15 \mathrm{~min}$ at $1 \mathrm{~h}$ intervals. LH was measured by radioimmunoassay before and after each $\mathrm{GnRH}$ pulse. Data from six independent experiments performed in triplicate were pooled. Asterisk indicates significance against control. Two-way ANOVA (repeated measures) with consecutive Bonferroni post-tests were applied. (B) Gene expression of SNAP-25 and munc-18 from control cells were determined immediately after $\mathrm{GnRH}$ pulses $1,3,5$, and 8 . Levels of mRNA after $48 \mathrm{~h}$ (basal) were set to $100 \%$ as controls. Data from three independent experiments performed in triplets were pooled. Asterisk indicates significance against basal. ${ }^{* *}$ indicates significance of the third pulse versus all other pulses for both SNAP-25 and munc-18 $(P<0.001)$. ANOVA with consecutive Dunnett's multiple comparison post-test were applied. ${ }^{*} P<0.05$; ${ }^{\star \star} P<0.01 ;{ }^{* \star} P<0.001$.

\section{Effects of estradiol on SNAP-25 and munc-18 gene expression in $\alpha \mathrm{T} 3-1$ cells}

Figure $4 \mathrm{~A}$ shows a significant decrease $(-22 \%)$ in SNAP-25 gene expression by treatment with $100 \mathrm{pM}$ estradiol for $48 \mathrm{~h}(P<0 \cdot 01)$. On the contrary, the gene expression of munc-18 was significantly increased (+ $33 \%$; $P<0.05$ ) by $100 \mathrm{pM}$ estradiol for $48 \mathrm{~h}$ (Fig. $4 \mathrm{~B}$ ). Incubation with $100 \mathrm{pM}$ estradiol for only $24 \mathrm{~h}$ had no
A

SNAP-25
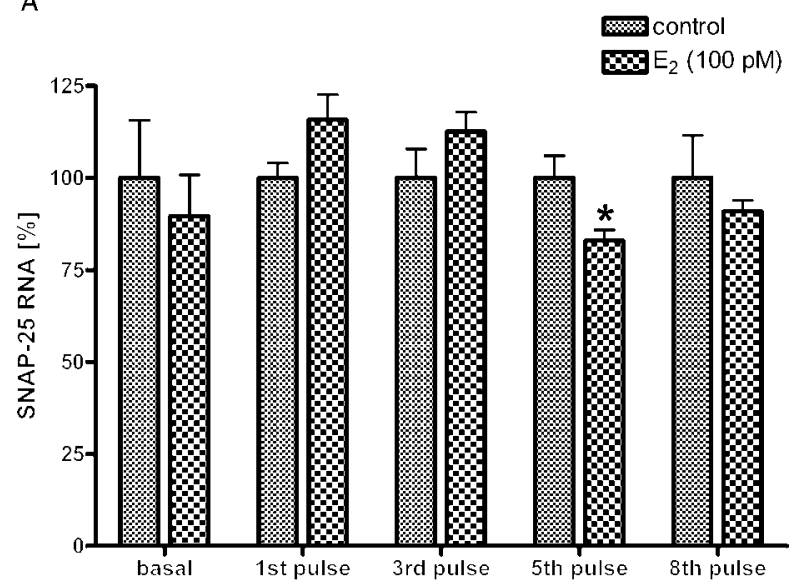

B

Munc-18
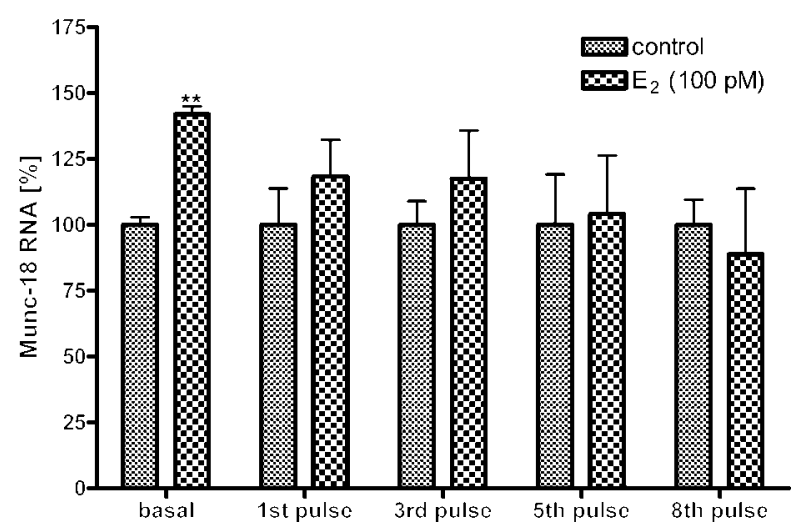

Figure 2 Effects of GnRH pulses and estradiol on the gene expression of SNAP-25 and munc-18. Mixed anterior pituitary cells were treated for $48 \mathrm{~h}$ with $100 \mathrm{pM}$ estradiol and stimulated with eight pulses of $1 \mathrm{nM} \mathrm{GnRH}$ for $15 \mathrm{~min}$ at $1 \mathrm{~h}$ intervals. SNAP-25 (A) and munc-18 (B) mRNA levels were determined at basal (after $48 \mathrm{~h}$ of estradiol treatment) and directly after $\mathrm{GnRH}$ pulses $1,3,5$, and 8 . Gene expression of untreated cells at each GnRH pulse was set to $100 \%$. Data from three independent experiments performed in triplicate were pooled. Asterisk indicates significance against control $\left({ }^{\star} P=0.028\right.$ for SNAP-25 and ${ }^{\star \star} P=0.012$ for munc-18). Unpaired $t$-test was performed for each pulse.

effect on the gene expression of neither SNAP-25 nor munc-18 (data not shown).

\section{Effects of estradiol on SNAP-25 and munc-18 protein expression in $\alpha \mathrm{T} 3-1$ cells}

The data on the protein expression of the exocytotic proteins are in keeping with the results on the gene expression. Again, long-term treatment with $100 \mathrm{pM}$ estradiol significantly decreased SNAP-25 protein expression by $34 \%(P<0 \cdot 0001$, Fig. $5 \mathrm{~A})$, whereas the expression of munc-18 was significantly enhanced by 


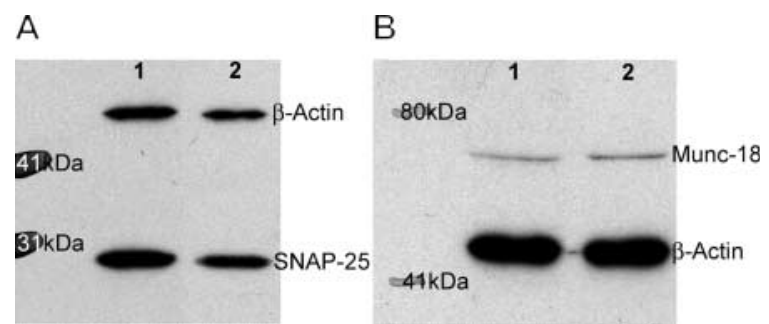

Figure 3 Representative immunoblots in $\alpha \mathrm{T} 3-1$ cells. Immunoblots of SNAP-25 and munc-18 in $\alpha$ T3- 1 cells. $\beta$-Actin was used as internal standard. Panel A shows SNAP-2 and Panel B shows munc-18. Lane 1 shows untreated control cells and lane 2 cells treated with estradiol.

$46 \%(P<0 \cdot 01$, Fig. 5B). The $24 \mathrm{~h}$ incubation of the cells with $100 \mathrm{pM}$ estradiol had no effect on SNAP-25 and munc-18 protein expression (data not shown).

\section{Effects of estradiol on SNAP-25 and munc-18 gene expression in single gonadotrophs}

To confirm our previous results, we performed experiments in single cells of rat pituitary gonadotrophs. Mixed populations of anterior pituitary cells contain around $10 \%$ gonadotrophs in intact rats and up to $30 \%$ in ovariectomized rats. Therefore, it is not possible to trace back effects exclusively to gonadotrophs in mixed anterior pituitary cell cultures. This was the reason why we here used immortalized murine-derived $\alpha$ T3-1 tumor cells consisting only of gonadotrophs. The normal secretion of the complete LH in this cell line is disturbed, however. We cannot exclude the possibility that this disturbed secretion is due to a defect in the exocytotic machinery. To solve that dilemma, we used single rat pituitary gonadotrophs. To identify gonadotrophs, we performed single-cell quantitative RT-PCR simultaneously always for LH- $\beta$ and either SNAP-25 or munc- 18 .

Our results in single rat gonadotrophs were congruent to the results gained in $\alpha \mathrm{T} 3-1$ cells. SNAP-25 gene expression (Fig. 6A) was significantly decreased by $87 \%$ $(P=0 \cdot 014)$ and munc-18 gene expression (Fig. 6B) was significantly increased $(+181 \%)$ in single gonadotrophs after long-term $(48 \mathrm{~h})$ estradiol treatment with $100 \mathrm{pM}$ $(P<0 \cdot 01)$. Figure 6C shows a representative gel with the PCR products for LH- $\beta$, munc-18, SNAP-25, and $\beta$-actin.

\section{Discussion}

Here, we demonstrated that long-term treatment of female gonadotrophs with estradiol oppositionally affected two important components of the exocytotic machinery of the pituitary gland. Estradiol suppressed SNAP-25 levels, whereas the expression of munc-18 was increased.

Only a few other investigators have tested the effects of estradiol on exocytotic proteins and the results have been
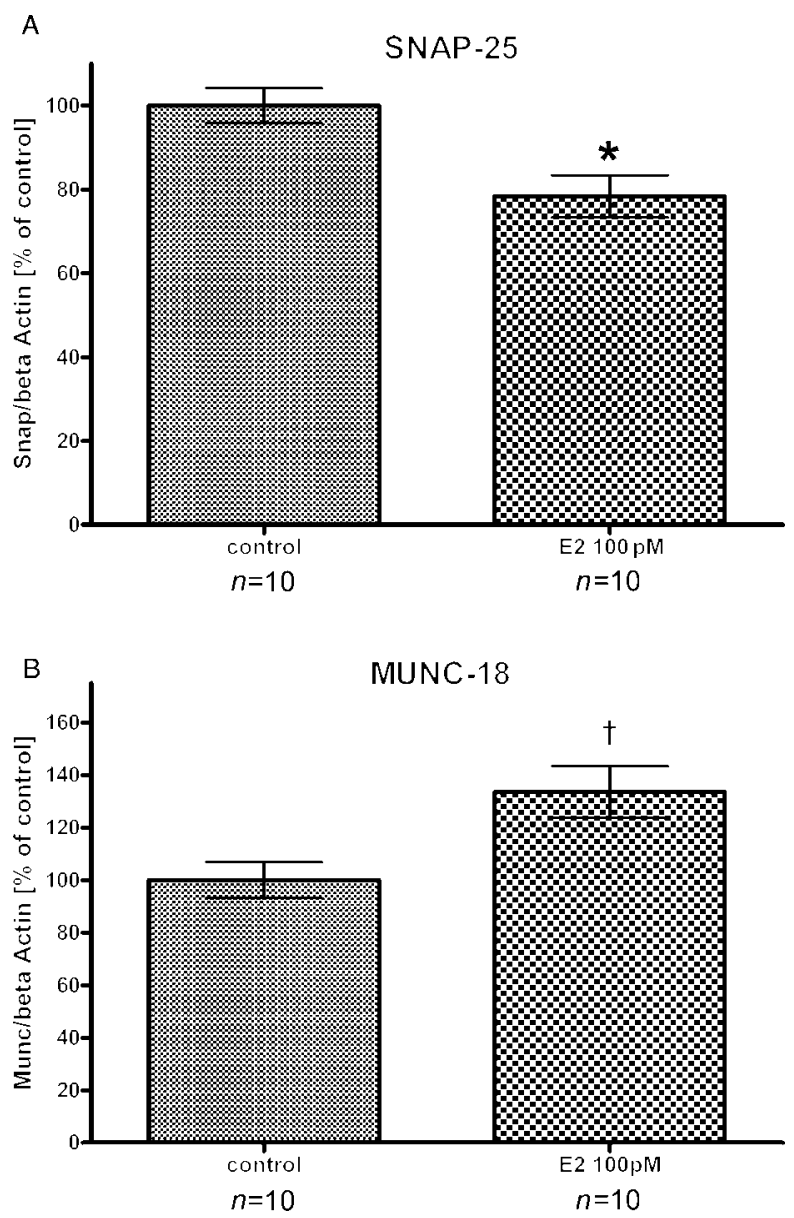

Figure 4 RT-PCR in $\alpha$ T3-1 cells. Cells were incubated with $100 \mathrm{pM}$ estradiol for $48 \mathrm{~h}$. mRNA of SNAP-25 (A) and munc-18 (B) were quantified by real-time RT-PCR. Data from 10 independent experiments performed in triplicates were pooled. Untreated controls were set to $100 \%$. ${ }^{*} P<0.01 ;{ }^{\dagger} P<0.05$ compared with control (unpaired $t$-test).

conflicting. Jacobsson et al. (1998) demonstrated that estradiol in vivo suppressed SNAP-25 gene expression in anterior lobes of pituitaries. Rats were treated for 21 days with estradiol capsules. They, however, found no influence of estradiol on other exocytotic proteins like VAMP2, Hrs-2 and munc-18. In keeping with that line, a lower expression of SNAP-25 protein in estrogen-induced tumors of the pituitary gland in Fisher 344 rats was detected (Majo et al. 1999). In contrast, others concluded that the expression of synaptic proteins including SNAP25 and munc-18 in ewes is not changed in the anterior pituitary at the time when LH secretion is maximal, i.e. after estradiol treatment (Thomas et al. 1998). Estradiol treatment of $\mathrm{GH}_{4} \mathrm{C}_{1}$ rat pituitary cells even increased SNAP-25 levels about $1 \cdot 5$-fold (Lee et al. 2000).

These results are in part contradictory to our findings. The differences might be due to different species and different cell lines used. These data suggest 


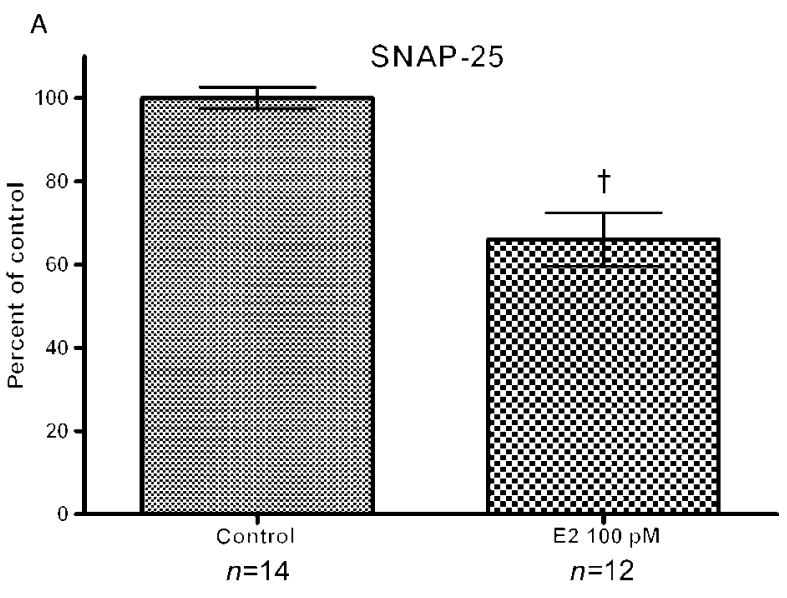

B

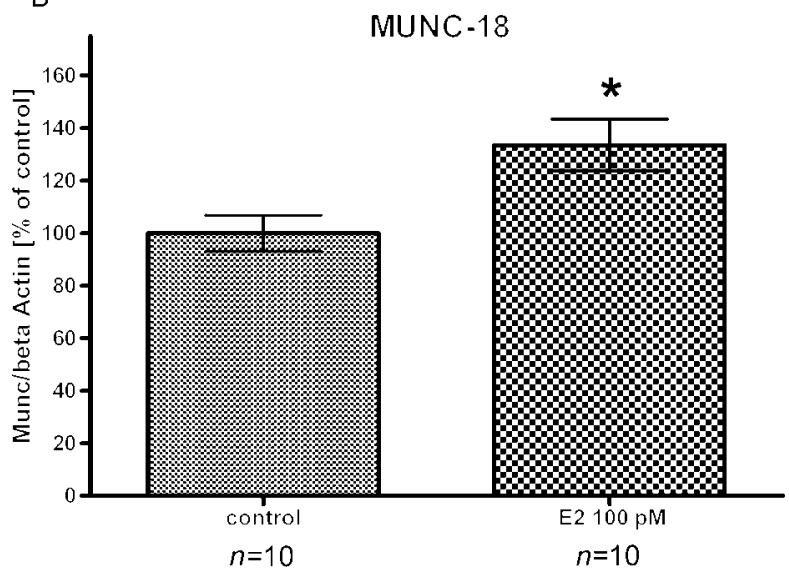

Figure 5 Immunoblots in $\alpha$ T3-1 cells. Cells were incubated with $100 \mathrm{pM}$ estradiol for $8 \mathrm{~h}$. SNAP-25 (A) and munc-18 (B) protein concentrations were quantified by western blot in relation to $\beta$-actin. Data from 12-14 independent experiments performed in triplicates were pooled. Untreated controls were set to $100 \%$. ${ }^{\star} P<0.01 ;{ }^{\dagger} P<0.0001$ compared with control (unpaired $t$-test).

that SNAP-25 regulation is not the same in $\mathrm{GH}_{4} \mathrm{C}_{1}$ cells, a prolactin-secreting cell line, and in ewes as it is in the normal rodent pituitary gland. Since no investigator examined the effects of estradiol particularly on gonadotrophs but on the entire anterior lobe of the pituitary, the differences in estradiol regulation might be due to the dominance of other compartments as well. The pituitary gland consists of several hormonesecreting cell types with only a small fraction of gonadotrophs $(5-10 \%)$. The literature to date deals either with the anterior pituitary on the whole, prolactin secreting cells, or tumors. Reviewing these articles concerning the effects of estradiol on SNAP-25, one may speculate that estradiol treatment decreased SNAP-25 in gonadotrophs, whereas in prolactin-secreting cells, SNAP-25 is increased after estradiol treatment. It fits well that human prolactinomas express more SNAP-25 than normal glands (Majo et al. 1997). That points at a different regulation of exocytosis in gonadotrophs and lactotrophs. Further studies on the different regulation of SNAP-25 mediated exocytosis in lacotrophs and gonadotrophs are warranted.

We aimed to delineate, how our findings fit into the current concepts of exocytosis and its regulation. Treatment of permeabilized male rat gonadotrophs with SNAP-25 antibodies diminished calcium-induced LH secretion, but did not influence basal LH secretion. Treatment with $100 \mathrm{nM} \mathrm{GnRH}$, either in vitro for 4 or $72 \mathrm{~h}$ or in vivo for 5 days twice a day, decreased SNAP-25 protein expression (Quintanar et al. 2004). This is in striking contrast to our results. We found a profound increase in both $S N A P-25$ and munc-18 gene expression after treatment with GnRH pulses. These differences might well be due to a very different experimental setting: we used female, not male rats and we measured gene, not protein expression in vitro. Furthermore, we applied $1 \mathrm{nM}$ GnRH for $15 \mathrm{~min}$ at $1 \mathrm{~h}$ intervals. This procedure is well established to mimic the physiological situation and has been used by other groups (Turgeon \& Waring 1999). Furthermore, we could demonstrate a significant decrease of SNAP-25 in GnRH-stimulated gonadotrophs by estradiol. On the other hand, the expression of munc-18 was significantly increased in non-agonist stimulated gonadotrophs treated with estradiol. The effects of estradiol on GnRH-stimulated cells were not that distinctive, since $\mathrm{GnRH}$ pulses alone led to a higher increase in munc-18 than in SNAP-25 expression. This vigorous rise might mask the additional effects of estradiol.

In our experiments, the LH secretory pattern in response to the agonistic stimulus GnRH is congruent to the response of SNAP-25 and munc-18 to GnRH with the maximal increase at the third pulse of GnRH. It is therefore conceivable that GnRH-induced LH secretion is associated with corresponding changes in the exocytotic proteins SNAP-25 and munc-18. As yet another contrast, here we gained evidence that the estradiol-induced increase in basal LH release leads to a reduced SNAP-25 expression. This indicates that basal LH release is not independent of SNAP-25. This may be explained by the fact that the enhanced LH secretion precipitates a depletion of SNAP-25. The function of SNAP-25 in the modulation of LH secretion by estradiol remains not fully elucidated. It is not clear what happens to SNAP-25 after membrane merger. WalchSolimena et al. (1995) found evidence that SNAP-25 is at least partially recycled at the synaptic cleft of neurons. Pituitary cells are able to recycle components of the exocytotic machinery (Ferraro et al. 2005). Massive stimulation of prolactin release in vitro leads to a depletion of the cellular levels of prolactin up to $80 \%$. Prolactin, for example, remains connected with the cell membrane after exocytosis and is ready for recycling and reuse. Others components like PAM-1, a 
membrane enzyme participating in the final steps of the biosynthesis of hormones, can be functionally recycled. There are no reports that clarify the fate of SNAP-25 after exocytosis in the pituitary gland occurred.

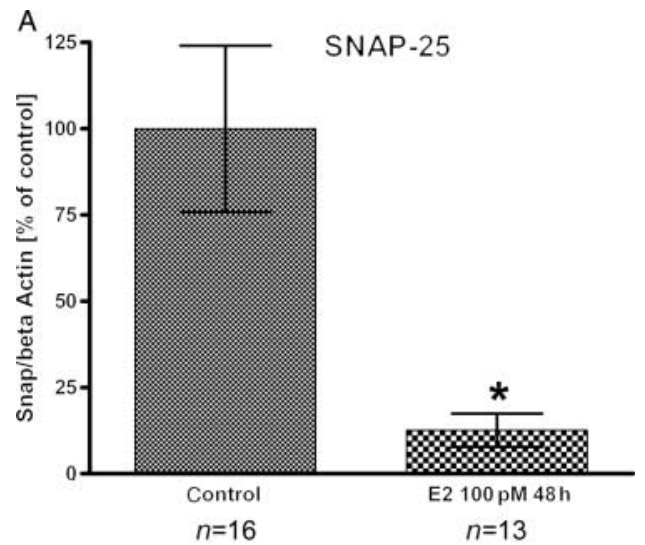

B

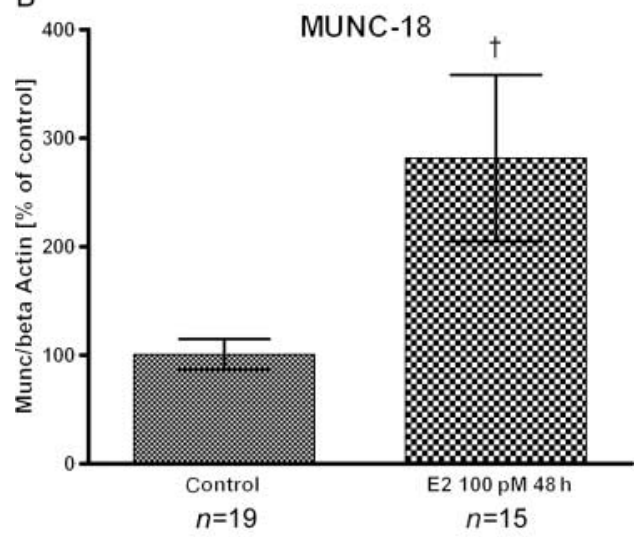

C

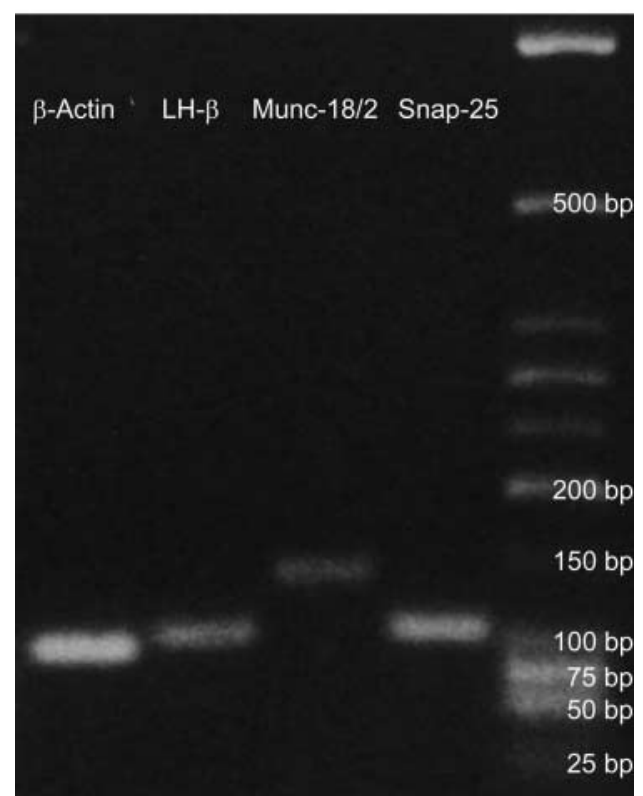

Korteweg et al. (2005) tested hormone levels in the anterior pituitaries of munc-18 null mutant mice. They found very low levels of circulating hormones and enhanced intracellular hormones. This underlines the importance of munc-18 for the secretion of hormones from anterior pituitary cells. They suggested that munc18 is important for the docking of vesicles, because large dense-core vesicles assembled close to, but not directly at the terminal membrane (Korteweg et al. 2005). This is in contrast to the findings of Verhage $e t$ al. (2000) that synaptic vesicles are distributed normally in synapses of munc-18 null mutant mice. This shows that the transfer of results derived from experiments in neuronal synapses to gonadotrophs is restricted.

Since it has been suggested that munc- 18 hampers the ability of syntaxin to form SNARE complexes, munc-18 might be a negative regulator of exocytosis and an overexpression of munc-18 should reduce hormone release. This could be true if the concentration of munc18 and syntaxin is equal, because they interact with a 1:1 stoichiometry (Misura et al. 2000). Schütz et al. (2005) found that syntaxin 1 expression is 20 times higher than munc-18 expression. In accordance with that, Toonen et al. (2005) argued against the possibility that munc-18 acts as a simple chaperone for syntaxin. Munc-18 has recently been identified as a positive regulator of exocytosis in PC12 cells (Schütz et al. 2005). They proposed a dual role for munc-18 switching between syntaxin binding and mint1 binding. Overexpression of mint1 inhibits exocytosis in PC12 cells. Binding of munc-18 to mint1 prevents mint1's negative effect on exocytosis. The first target of munc-18 is syntaxin, because of the high-affinity of their binding. Higher cytosolic munc-18 however leads to a higher binding to mint1 and consecutively to an increase in hormone release. An overexpression of the cytoplasmic region of syntaxin thus leads to an inhibition of secretion from PC12 cells (Dulubova et al. 1999). Furthermore, munc-18 is required for the stability of syntaxin. Munc18 null mutant mice expressed lower levels of syntaxin 1 , but other proteins of the exocytotic machinery remained unaffected. Even in the absence of munc-18, syntaxin 1 can be targeted properly (Toonen et al. 2005). The lack of munc-18 may lead to an uncontrolled binding of syntaxin 1 to other, non-cognate, exocytotic proteins, which in turn could hamper cell viability. Toonen et al. (2005) did not find evidence for

Figure 6 RT-PCR in single gonadotrophs. Rat anterior pituitary cells were incubated with $100 \mathrm{pM}$ estradiol for $48 \mathrm{~h}$. Single gonadotrophs were extracted and identified. mRNA of SNAP-25 (A) and munc-18 (B) from a single cell was quantified by real-time RT-PCR in relation to $\beta$-actin. Data from 13-19 experiments performed in duplicates were pooled. Untreated controls were set to $100 \%$. A: ${ }^{\star} P<0.0034$; $\mathrm{B}:{ }^{\dagger} P<0.0141$ (Unpaired $t$-test was applied). $C$ shows a representative gel with the PCR products for LH- $\beta$, munc-18, SNAP-25, and $\beta$-actin. 
detrimental effects of the promiscuous syntaxin 1 binding on cell viability. The SNARE complexes formed might not be accessible for normal exocytosis, since munc-18 null-mutant mice have no transmitter release (Verhage et al. 2000). Munc-18 may have a crucial and autonomous function in conjunction with syntaxin 1 in exocytosis (Toonen et al. 2005).

The concepts of Schütz et al. (2005) and Toonen et al. (2005) are in keeping with our results. Estradiol treatment leads to an up-regulation of munc-18 and consecutively to increased LH secretion. Therefore, munc-18 is a crucial component of the modulation of LH secretion by estradiol.

Other concepts on how estradiol could positively regulate LH secretion are well established. Estradiol modulates GnRH receptor number (Gregg et al. 1990) and its gene expression (Bauer-Dantoin et al. 1993). Moreover, estradiol could affect components of the GnRH signal transduction such as calcium signaling and inositol phosphates (Ortmann et al. 1992, 1995).

However, those concepts could not fully explain the positive modulatory effect of estradiol on basal and agonist induced LH secretion. Therefore, our findings add novel evidence to the hypothesis that estradiol affects even distant mechanisms of signal transduction like exocytosis.

In conclusion, long-term estradiol treatment negatively regulates the exocytotic protein SNAP-25 and positively affects the regulation of munc-18 in female gonadotrophs. The up-regulation of munc-18 is another mechanism by which estradiol might enhance LH secretion from female gonadotrophs.

\section{Acknowledgements}

We thank Dr P Mellon (San Diego) for providing $\alpha \mathrm{T} 3-1$ cells.

\section{Funding}

This work was supported by a grant from the Deutsche Forschungsgemeinschaft (DFG Or 52/8-1). There is no conflict of interest that would prejudice our impartiality.

\section{References}

Aguado F, Majo G, Ruiz-Montasell B, Canals JM, Casanova A, Marsal J \& Blasi J 1996 Expression of synaptosomal-associated protein SNAP-25 in endocrine anterior pituitary cells. European Journal of Cell Biology 69 351-359.

Bauer-Dantoin AC, Hollenberg AN \& Jameson JL 1993 Dynamic regulation of gonadotropin-releasing hormone receptor mRNA levels in the anterior pituitary gland during the rat estrous cycle. Endocrinology 133 1911-1914.
Borisovska M, Zhao Y, Tsytsyura Y, Glyvuk N, Takamori S, Matti U, Rettig J, Sudhof T \& Bruns D 2005 v-SNAREs control exocytosis of vesicles from priming to fusion. EMBO Journal 24 2114-2126.

Chen YA \& Scheller RH 2001 SNARE-mediated membrane fusion. Nature Reviews Molecular Cell Biology 2 98-106.

Dulubova I, Sugita S, Hill S, Hosaka M, Fernandez I, Sudhof TC \& Rizo J 1999 A conformational switch in syntaxin during exocytosis: role of munc18. EMBO Journal 18 4372-4382.

Ferraro F, Eipper BA \& Mains RE 2005 Retrieval and reuse of pituitary secretory granule proteins. Journal of Biological Chemistry $\mathbf{2 8 0}$ 25424-25435.

Gregg DW, Allen MC \& Nett TM 1990 Estradiol-induced increase in number of gonadotropin releasing hormone receptors in cultured ovine pituitary cells. Biology of Reproduction 43 1032-1036.

Jacobsson G \& Meister B 1996 Molecular components of the exocytotic machinery in the rat pituitary gland. Endocrinology 137 5344-5356.

Jacobsson G, Razani H, Ogren SO \& Meister B 1998 Estrogen downregulates mRNA encoding the exocytotic protein SNAP-25 in the rat pituitary gland. Journal of Neuroendocrinology 10 157-163.

Jahn R 2000 Sec1/Munc18 proteins: mediators of membrane fusion moving to center stage. Neuron 27 201-204.

Kolk SM, Groffen AJ, Tuinhof R, Ouwens DT, Cools AR, Jenks BG, Verhage M \& Roubos EW 2004 Differential distribution and regulation of expression of synaptosomal-associated protein of $25 \mathrm{kDa}$ isoforms in the Xenopus pituitary gland and brain. Neuroscience 128 531-543.

Korteweg N, Maia AS, Thompson B, Roubos EW, Burbach JP \& Verhage M 2005 The role of Munc18-1 in docking and exocytosis of peptide hormone vesicles in the anterior pituitary. Biology of the Cell 97 445-455.

Lee MS, Zhu YL, Sun Z, Rhee H, Jeromin A, Roder J \& Dannies PS 2000 Accumulation of synaptosomal-associated protein of $25 \mathrm{kDa}$ (SNAP-25) and other proteins associated with the secretory pathway in GH4C1 cells upon treatment with estradiol, insulin, and epidermal growth factor. Endocrinology 141 3485-3492.

Majo G, Ferrer I, Marsal J, Blasi J \& Aguado F 1997 Immunocytochemical analysis of the synaptic proteins SNAP-25 and Rab3A in human pituitary adenomas. Overexpression of SNAP-25 in the mammmosomatotroph lineages. Journal of Pathology 183 440-446.

Majo G, Lorenzo MJ, Blasi J \& Aguado F 1999 Exocytotic protein components in rat pituitary gland after long-term estrogen administration. Journal of Endocrinology 161 323-331.

Masumoto N, Ikebuchi Y, Matsuoka T, Tasaka K, Miyake A \& Murata Y 1997 Involvement of SNAP-25 in TRH-induced exocytosis in pituitary GH4C1 cells. Journal of Endocrinology 153 R5-R10.

Misura KM, Scheller RH \& Weis WI 2000 Three-dimensional structure of the neuronal-Sec1-syntaxin la complex. Nature $\mathbf{4 0 4}$ 355-362.

Ortmann O, Sturm R, Knuppen R \& Emons G 1990 Weak estrogenic activity of phenol red in the pituitary gonadotroph: re-evaluation of estrogen and antiestrogen effects. Journal of Steroid Biochemistry $\mathbf{3 5}$ $17-22$.

Ortmann O, Stojilkovic SS, Cesnjaj M, Emons G \& Catt KJ 1992 Modulation of cytoplasmic calcium signaling in rat pituitary gonadotrophs by estradiol and progesterone. Endocrinology 131 1565-1567.

Ortmann O, Bakhit M, Bloh P, Schulz KD \& Emons G 1995 Ovarian steroids modulate gonadotropin-releasing hormone-induced biphasic luteinizing hormone secretory responses and inositol phosphate accumulation in rat anterior pituitary cells and alpha T3-1 gonadotrophs. Journal of Steroid Biochemistry and Molecular Biology 54 101-109.

Ortmann O, Tomic M, Weiss JM, Diedrich K \& Stojilkovic SS 1998 Dual action of androgen on calcium signaling and luteinizing hormone secretion in pituitary gonadotrophs. Cell Calcium $\mathbf{2 4}$ 223-231. 
Quintanar JL, Salinas E, Chavez-Morales RM \& Quintanar-Stephano A 2004 Pituitary synaptic protein SNAP-25 sensitive to GnRH is necessary for LH release. Endocrine Regulations 38 1-6.

Rettig J \& Neher E 2002 Emerging roles of presynaptic proteins in $\mathrm{Ca}^{++}$-triggered exocytosis. Science 298 781-785. Erratum in: Science 2981336.

Schütz D, Zilly F, Lang T, Jahn R \& Bruns DA 2005 A dual function for Munc-18 in exocytosis of PC12 cells. European Journal of Neuroscience 21 2419-2432.

Sorensen JB, Matti U, Wei SH, Nehring RB, Voets T, Ashery U, Binz T, Neher E \& Rettig J 2002 The SNARE protein SNAP-25 is linked to fast calcium triggering of exocytosis. PNAS 99 1627-1632. Erratum in: PNAS 996449.

Stojilkovic SS $2005 \mathrm{Ca}^{2+}$-regulated exocytosis and SNARE function. Trends in Endocrinology and Metabolism 16 81-83.

Sudhof TC 1995 The synaptic vesicle cycle: a cascade of proteinprotein interactions. Nature 375 645-653.

Thomas SG, Takahashi M, Neill JD \& Clarke IJ 1998 Components of the neuronal exocytotic machinery in the anterior pituitary of the ovariectomised ewe and the effects of oestrogen in gonadotropes as studied with confocal microscopy. Neuroendocrinology 67 244-259.
Toonen RF, de Vries KJ, Zalm R, Sudhof TC \& Verhage M 2005 Munc18-1 stabilizes syntaxin 1, but is not essential for syntaxin 1 targeting and SNARE complex formation. Journal of Neurochemistry 93 1393-1400.

Turgeon JL \& Waring DW 1999 Androgen modulation of luteinizing hormone secretion by female rat gonadotropes. Endocrinology 140 $1767-1774$.

Verhage M, Maia AS, PlompJJ, Brussaard AB, Heeroma JH, Vermeer H, Toonen RF, Hammer RE, van den Berg TK, Missler M et al. 2000 Synaptic assembly of the brain in the absence of neurotransmitter secretion. Science 287 864-869.

Voets T, Toonen RF, Brian EC, de Wit H, Moser T, Rettig J, Sudhof TC, Neher E \& Verhage M 2001 Munc18-1 promotes large dense-core vesicle docking. Neuron 31 581-591.

Walch-Solimena C, Blasi J, Edelmann L, Chapman ER, von Mollard GF \& Jahn R 1995 The t-SNAREs syntaxin 1 and SNAP-25 are present on organelles that participate in synaptic vesicle recycling. Journal of Cellular Biology 128 637-645.

Received in final form 3 November 2006

Accepted 30 November 2006

Made available online as an Accepted Preprint 13 December 2006 